\title{
Facebook for Educational Purposes: Its Actual Usage and Issues Encountered by Senior High School Students
}

\author{
Charlotte Mojar, Dea Illy Coral, Micca Ela Balagon, Rufaina Harun, Ranelle Sonet, Jake Visitacion and Romenick A. \\ Molina \\ Zamboanga City State Polytechnic College, Philippines \\ DOI: https://dx.doi.org/10.47772/IJRISS.2021.5408
}

\begin{abstract}
The recent COVID-19 pandemic brought a lot of changes globally particularly in education sector. With this, teachers used different platforms to serve as an avenue for teaching - learning and one of which is the use of Facebook. This study utilized descriptive quantitative research. A total of 210 student - respondents answered the questionnaire, which was adapted and modified from Nguyen (2017). Frequency, mean and t-test were used to analyze the generated data. Results revealed that majority of the students used smartphone as a device to access Facebook and they were connected with their friends and teachers. They used Facebook daily and spend 1 to 6 hours per week. In addition, Facebook was being used as learning platform. Most students used Facebook to get information and to communicate with their classmates about school-related topics. When data on actual usage of Facebook were grouped according to gender, significant difference exists, while, there was no significant difference when the data were grouped according to track. The common issues encountered by the students were poor internet connectivity, verification of education-related resources and easily distracted by other Facebook contents. When data were grouped according to gender and track, results revealed that there were no significant difference.
\end{abstract}

Keywords: Facebook, Senior High School, Educational Purposes, Learning Platforms

\section{INTRODUCTION}

$\mathrm{T}$ he Covid-19 pandemic causes global imbalances and challenges in different sectors such as in health, business and education (Sakketa \& Khoeber, 2020; Sumner et. al., 2020). One of the measures implemented to reduce the spread of coronavirus is the temporary closure of academic institutions. Nonetheless, for the teachers to continue to cater for their students, the use of different teaching - learning delivery approaches were adopted. These are modular, pure online and blended learning approach.

The type of approaches to be implemented depends on the accessibility to both teachers and students. Modular approach is preferred, if students do not have any gadget and internet connection at all. In this approach, an individualized instructional materials were being printed and distributed to the students which serve as guides throughout the lessons, activities, and assessments (Malaya, 2020). Students with gadgets and stable internet connection prefers to be engaged in pure online. In this approach, teachers use application such as Google Classroom and Schoology. Students with gadgets yet unstable internet connection prefers to be engaged in blended learning. Blended learning used both online and modular approach to increase students' understanding, interaction and involvement (Jane \& Ellen, 2021).

Since engaging in pure online or blended learning can be costly, teachers and students tend to explore different application that is less expensive. One of the possible platform that can be used for learning is Facebook. It is a social networking application that helps people to connect and entertain users (Isaac, 2021). In the Philippines, Facebook is a popular application. Hence, it is being used by 74 million Filipino (Martha, 2020).

Due to the current health crisis, Facebook is being explored as an avenue for teaching and learning. Hence, students show good perception and positive attitude towards the use of Facebook (Oducado, et al., 2019).Thus, this study, aimed at determining the actual issues encountered by the students when using Facebook for educational purposes. Specifically, it aimed at the following questions:

a. What is the general usage of Facebook as perceived by the student - respondents?

b. What is the actual usage of Facebook for educational purposes?

c. How can a significant difference be established in the actual usage of Facebook for educational purposes when data were grouped according to gender and track?

d. What are the issues encountered by the student respondents when using Facebook for educational purposes?

e. How can a significant difference be determined in the issues encountered by the student - respondents when using Facebook for educational purposes when data were grouped according to gender and track?

\section{METHODS}

Research Design 
The researchers utilized descriptive quantitative to determine the actual usage and issues encountered by the students when using Facebook for educational purposes.

\section{Respondents of the Study}

The respondents of the study were Senior High School Students of an Academic Institution in Zamboanga City, Philippines. The students were selected through total enumeration. A total of 210 respondents participated in the study. Table 1 shows the profile of the respondents.

Table 1: Respondents of the Study $(n=210)$

\begin{tabular}{|c|c|c|}
\hline Gender & Frequency & Percentage \\
\hline Male & 117 & $56 \%$ \\
\hline Female & 93 & $44 \%$ \\
\hline Tracks & 42 & $20 \%$ \\
\hline Academic & 168 & $80 \%$ \\
\hline $\begin{array}{c}\text { Technical- } \\
\text { Vocational } \\
\text { Livelihood }\end{array}$ & \\
\hline
\end{tabular}

\section{Research Instrument}

The research instrument used in the study was adopted and modified from Nguyen (2017). The questionnaire is divided into 3 parts. Part 1 was on General Usage of Facebook Patterns; Part 2 was on Actual Usage of Facebook for Educational Purposes; and Part 3 was on the Issues Encountered when using Facebook for Educational Purposes. The instrument were validated by 2 experts and it obtained an Aiken validity value of 0.81 . According to Elvionita et al. (2019), an Aiken value greater than 0.60 indicates that the instrument is valid.

\section{Data Gathering Procedure}

The researchers sent a request letter to the Senior High School principal to allow the conduct of the study. Upon approval, the researchers reached out the respondents through Facebook messenger app. The researchers oriented the respondents about the nature and purpose of the study, then the researchers sent the questionnaire in Google form. The respondents clickedon "submit button" after answering the questionnaire.

\section{Analysis of Data}

Frequency and Percentage was used to summarize the responses on the General Usage of Facebook Patterns. Mean was used to determine the Actual Usage and Issues Encountered by the Respondents when using Facebook for Educational Purposes. And the T-test was used to compare the result on actual usage and issues encountered when respondents were grouped into sex and track.

\section{RESULT AND DISCUSSION}

Facebook is an application used by many people due to its accessibility and low data consumption. Table 2 shows the general usage of Facebook as perceived by the student respondents.

Table 2: General Usage of Facebook $(n=210)$

\begin{tabular}{|c|c|c|}
\hline \multicolumn{3}{|c|}{ 1. Which device/s do use for Facebook? } \\
\hline Choices & Frequency & Percentage \\
\hline Smartphone & 187 & $89 \%$ \\
\hline Laptop & 9 & $4.3 \%$ \\
\hline Desktop & 5 & $2.4 \%$ \\
\hline Tablet & 4 & $1.9 \%$ \\
\hline \multicolumn{3}{|c|}{ 2. Are you connected with your classmates on Facebook? } \\
\hline Choices & Frequency & Percentage \\
\hline Yes & 192 & $92.4 \%$ \\
\hline No & 16 & $7.6 \%$ \\
\hline \multicolumn{3}{|c|}{ 3. Are you connected with your teachers on Facebook? } \\
\hline Choices & Frequency & Percentage \\
\hline Yes & 178 & $84.8 \%$ \\
\hline No & 34 & $15.2 \%$ \\
\hline \multicolumn{3}{|c|}{ 4. How often do you use Facebook in general? } \\
\hline Choices & Frequency & Percentage \\
\hline $\begin{array}{l}\text { Daily/ Almost } \\
\text { Daily }\end{array}$ & 160 & $76.2 \%$ \\
\hline $\begin{array}{l}\text { Weekly/almost } \\
\text { weekly }\end{array}$ & 43 & $20.5 \%$ \\
\hline $\begin{array}{l}\text { Few times a } \\
\text { month }\end{array}$ & 7 & $3.3 \%$ \\
\hline \multicolumn{3}{|c|}{$\begin{array}{l}\text { 5. How much time per week do you averagely spend being } \\
\text { active on Facebook? }\end{array}$} \\
\hline Choices & Frequency & Percentage \\
\hline $\begin{array}{l}\text { Less than } 1 \\
\text { hour }\end{array}$ & 77 & $36.7 \%$ \\
\hline 1 to 6 hours & 87 & $41.4 \%$ \\
\hline 7 to 10 hours & 28 & $13.3 \%$ \\
\hline 11 to 20 hours & 18 & $8.6 \%$ \\
\hline \multicolumn{3}{|c|}{$\begin{array}{l}\text { 6. Is this your first time to use Facebook as virtual learnin } \\
\text { environment? }\end{array}$} \\
\hline Choices & Frequency & Percentage \\
\hline Yes & 165 & $78.6 \%$ \\
\hline No & 45 & $21.4 \%$ \\
\hline
\end{tabular}

It can be seen that majority of the student - respondents( $89 \%)$ used smartphone as devices to access Facebook. This findings concur the idea of Alondres et al. (2018) and Tankovska (2021) that most of users accessed Facebook using mobile phone. It can also be seen that most of the student respondents are connected to their classmates $(92.4 \%)$ and teachers (84\%). According to Baruch \& Hershkovitz (2013), student-teacher relationships are vital for students' academic development and well-being. Most of the student respondents(76.2\%) used Facebook on daily basis, with an average exposure of 1 to 6 hours per week. Hence, students used Facebook to communicate with their friends daily and lasts for less than an hour (Hassan, 2014). More so, more than 
a half of the respondents (78.6\%) are new on using Facebook as virtual learning environment. Due to the COVID19 pandemic, the purpose of Facebook as social networks application shifted into educational platform (Hassan, 2014).

Since student respondents used Facebook as a learning platform in their various subjects. Table 3 shows the Actual Usage of the Facebook for Educational Purposes.

Table 3: Actual Usage of Facebook for Educational Purposes

\begin{tabular}{|l|l|l|}
\hline \multicolumn{1}{|c|}{ Activities } & Mean & $\begin{array}{c}\text { Descriptive } \\
\text { Ratings }\end{array}$ \\
\hline $\begin{array}{l}\text { I use Facebook to communicate with my } \\
\text { classmates about school-related topics. }\end{array}$ & 4.50 & Always \\
\hline $\begin{array}{l}\text { I use Facebook to contact my lectures about subject } \\
\text { related topics. }\end{array}$ & 4.25 & Often \\
\hline $\begin{array}{l}\text { I use Facebook to get information of any } \\
\text { announcements regarding courses, classes, or } \\
\text { schools' issues. }\end{array}$ & 4.52 & Always \\
\hline $\begin{array}{l}\text { I use Facebook to get support from Facebook } \\
\text { community for my homework/ assignments (for } \\
\text { example by asking for comments/advice or } \\
\text { conducting surveys for research). }\end{array}$ & 4.04 & Often \\
\hline $\begin{array}{l}\text { I use Facebook to contact experienced people for } \\
\text { sharing school experiences or asking for academic } \\
\text { advice. }\end{array}$ & 3.78 & Often \\
\hline $\begin{array}{l}\text { I use Facebook to facilitate group task/projects for } \\
\text { my study (to set up working space and interact with } \\
\text { each other). }\end{array}$ & 3.87 & Often \\
\hline $\begin{array}{l}\text { I use Facebook to join in beyond school projects' } \\
\text { activities that are related to or would benefit my } \\
\text { studies at school. }\end{array}$ & 3.91 & Often \\
\hline $\begin{array}{l}\text { I use Facebook to join Facebook } \\
\text { groups/communities of similar academic } \\
\text { focuses/interests for self-studying and } \\
\text { improvement. }\end{array}$ & 3.93 & Often \\
\hline $\begin{array}{l}\text { I use Facebook to get access to/share academic } \\
\text { resources or learning materials through Facebook } \\
\text { (such as course handouts, self-study, materials, } \\
\text { etc.) }\end{array}$ & 4.04 & Often \\
\hline $\begin{array}{l}\text { Bookmarks/save relevant/useful resources for my } \\
\text { studies. }\end{array}$ & 4.11 & Often \\
\hline
\end{tabular}

Legend: 4.5-5.00-Always $\quad 3.5-4.9-$ Often $\quad 1.5-2.49$-Seldom $\quad 1.0$ 1.49-Never

It can be seen in Table 2 that the common usage of Facebook of the student - respondents is to get any announcements and to communicate with their classmates about school-related topics with mean scores of 4.52 and 4.50 respectively. It implies that students use Facebook for update purposes. Hence, Hassan (2014) pointed out that the purpose of Facebook is to serve as a communication tool for their friends to discuss topics of their common interests and activities. On the other hand, the least usage of Facebook is to contact experienced people to share school related knowledge and to facilitate group task/projects, since it obtained the lowest mean score of 3.78 and 3.87 respectively. This is due to the interplay of demographic cultural and personal factors (Ashwari \& Stefan, 2012). More so, students do not want to engage their selves in online socialization (Doug \& Marje, 2009).

The result on actual usage of Facebook were grouped according to gender and track to determine if significant difference exists. Table 4 shows the actual usage of Facebook when data were grouped according to gender and track.

Table 4: Actual Usage of Facebook for Educational Purpose According to Gender and Track

\begin{tabular}{|c|c|c|c|c|c|}
\hline Variable & $\mathrm{N}$ & Mean & T-Stat & $\begin{array}{c}\mathrm{T}- \\
\text { Critical } \\
\end{array}$ & Interpretation \\
\hline \multicolumn{6}{|l|}{ Gender } \\
\hline Male & 117 & 3.95 & \multirow{2}{*}{3.38} & \multirow{2}{*}{1.97} & \multirow{2}{*}{ Significant } \\
\hline Female & 93 & 4.26 & & & \\
\hline \multicolumn{6}{|l|}{ Track } \\
\hline Academic & 42 & 3.96 & \multirow{2}{*}{0.86} & \multirow{2}{*}{2.00} & \multirow{2}{*}{$\begin{array}{c}\text { Not } \\
\text { Significant }\end{array}$} \\
\hline TVL & 168 & 4.07 & & & \\
\hline
\end{tabular}

In terms of gender, it canbe seen that the computed T Stat value is 3.38 , which is greater than the $\mathrm{T}$ - Critical value of 1.97 , thus, there is a significant difference in the actual usage of Facebook for educational purposes between male and female students. The result implied that there were more female students (Mean $=4.26)$ used Facebook for educational purposes than male $($ Mean $=3.95)$.

In terms of track, it can be seen that the computed T Stat value is 0.86 , which is less than the $\mathrm{T}-$ Critical value of 2.00 , thus, there is no significant difference on the actual usage of Facebook for educational purposes between academic and TVL track students. The result implied that regardless of track, students used Facebook for educational purposes, considering that the mean of academic is 3.96

It cannot be avoided that students may encounter some issues when using Facebook for educational purposes. Table 5 shows the issues encountered by the students when using Facebook for educational purposes.

Table 5: Issues Encountered when Using Facebook

\begin{tabular}{|l|c|c|}
\hline \multicolumn{1}{|c|}{ Indicator } & Mean & $\begin{array}{c}\text { Descriptive } \\
\text { Rating }\end{array}$ \\
\hline $\begin{array}{l}\text { I am easily distracted by other } \\
\text { Facebook contents/activities. }\end{array}$ & 4.19 & Often \\
\hline $\begin{array}{l}\text { I used to miss important } \\
\text { announcements. }\end{array}$ & 4.11 & Often \\
\hline I encounter miscommunication. & 4.11 & Often \\
\hline $\begin{array}{l}\text { I feel suspicious/confused on education- } \\
\text { related resources/ materials shared on } \\
\text { Facebook. }\end{array}$ & 4.20 & Often \\
\hline $\begin{array}{l}\text { I give attention on references when } \\
\text { using educational materials found on } \\
\text { Facebook. }\end{array}$ & 4.13 & Often \\
\hline $\begin{array}{l}\text { I feel uncomfortable/annoyed when } \\
\text { mixing my personal life and academic } \\
\text { life on Facebook. }\end{array}$ & 4.14 & Often \\
\hline $\begin{array}{l}\text { I get easily irritated when using due to } \\
\text { poor internet connection. }\end{array}$ & 4.40 & Often \\
\hline
\end{tabular}

Legend: 4.5-5.00-Always 3.5-4.9-Often 1.0-1.49-Never

It can be seen that poor internet connection is one of the common problem encountered by the students. Hence, it obtained a mean score of 4.40 . Another issue emerged is the 
verification of educational materials found on Facebook with a mean score of 4.20. According to Elisa and Elizabeth (2019), fake information was proliferated in Facebook. Another issue emerged is being easily distracted on Facebook contents. Hence, it obtained a mean score of 4.19. Chandra (2018) stated that users spend too much time because Facebook is very entertaining.

The result on issues encountered when using Facebook for educational purposes were grouped according to gender and track to determine if significant difference exists. Table 6 shows the issues encountered on using Facebook when data were grouped according to gender and track.

Table 6: Issues Encountered When Using Facebook for Educational Purpose According to Gender and Track

\begin{tabular}{|c|c|c|c|c|c|}
\hline Variable & $\mathrm{N}$ & Mean & T-Stat & T-Critical & Interpretation \\
\hline \multicolumn{6}{|l|}{ Gender } \\
\hline Male & 117 & 3.93 & \multirow{2}{*}{1.41} & \multirow{2}{*}{1.97} & \multirow{2}{*}{$\begin{array}{c}\text { Not } \\
\text { Significant }\end{array}$} \\
\hline Female & 93 & 4.05 & & & \\
\hline \multicolumn{6}{|l|}{ Track } \\
\hline Academic & 42 & 3.97 & \multirow{2}{*}{0.05} & \multirow{2}{*}{0.96} & \multirow{2}{*}{$\begin{array}{c}\text { Not } \\
\text { Significant }\end{array}$} \\
\hline TVL & 168 & 3.98 & & & \\
\hline
\end{tabular}

In terms of gender, it can be seen that the computed T Stat value is 1.41 , which is less than the $\mathrm{T}-$ Critical value of 1.97 , thus, there is no significant difference on the issues encountered by male and female students when using Facebook for educational purposes. The result implied that both male and female students encountered issues when using Facebook for educational purposes, considering that mean score of male and female is 3.93 and 4.05 respectively.

In terms of track, it can be seen that the computed T Stat value is 0.05 , which is less than the $\mathrm{T}-$ Critical value of 0.96 , thus, there is no significant difference on the issues encountered by academic and TVL students when using Facebook for educational purposes. The result implied that both tracks encountered issues when using Facebook for educational purposes, considering that mean score of academic and TVL is 3.97 and 3.98 respectively.

\section{CONCLUSION}

Facebook is being used as a learning platform. Most of the students used Facebook to get information and to communicate with their classmates about school-related topics. There was a significant difference on the actual usage of Facebook when data were grouped according to gender, while there was no significant difference when the data were grouped according to track. The common issues encountered when using Facebook were poor internet connectivity, verification of education-related resources and easily distracted by other Facebook contents. There was no significant difference on the issues encountered when data were grouped according to gender and track.

\section{REFERENCES}

[1] Alondres et al., (2018). The Impact of Facebook Usage to the Academic Performance of the 4th Year Education Students in Andres Bonifacio College. Retrieved from https://www.slideshare.net/AnjenetteColumnas/research-thesisthe-impact-of-facebook-usage-to-the-academic-performance-ofthe-4th-year-education-students-in-andres-bonifacio-college on March 02, 2021

[2] Ashwani \& Stefan (2012). Why Do People Used Facebook? Personality and Individual Differences. 52(3), 243-249. doi:10.1016/paid.2011.11.007

[3] Baruch \& Hershkovitz (2013). Student- teacher relationship in the Facebook era: the student perspective. International Journal of Continuing Engineering Education and Life-long Learning.23(1), 33-52. doi: 10.1504/1JCEEL.2013.051765.

[4] Beek, M. V. (2011, January 27). Introduction: What Is "Virtual Learning"? Retrieved from https://www.mackinac.org/14475 on November 04, 2021.

[5] Chandra, R (2018). Is Facebook Destroying Society and Your Mental Health? $\quad$ Retrieved from https://www.psychologytoday.com/us/blog/the-pacificheart/201801/is-facebook-destroying-society-and-your-mentalhealth on March 05, 2021.

[6] Doug \&Marje (2009). The Impact of Facebook on our Students. Retrieved from https://www.nais.org/articles/pages/the-impact-offacebook-on-our-students on March 05, 2021.

[7] Elisa \& Elizabeth (2019). Americans are Wary of the Role Social Media Sites Play in Delivering the News. Retrieved From https://www.journalism.org/2019/10/02/americans-are-wary-ofthe-role-social-media-sites-play-in-delivering-the-news/ on March 05, 2021.

[8] Fox, B. (2017). Social Media and Education: Using Social Media for Better Academic Results. Retrieved from https://medium.com/@braydenfox/social-media-and-educationusing-social-media-for-better-academic-results-804b7a41a825 on March 02,2021.

[9] Hassan, I. S. (2014). Facebook as a Tool for Teaching and Learning. JURNAL PENDIDIKAN MALAYSIA. 8-8

[10] Isaac, M. (2021). Facebook is said to be building a product to compete with clubhouse. New York Times. Retrieved from https://indianexpress.com/article/technology/social/facebookbuilding-product-rival-clubhouse-7183816/ on March 02, 2021.

[11] Jane \& Ellen (2011). Adopting a Blended Learning Approach: Challenges Encountered and Lessons Learned in an Action Research Study. Journal of Asynchronous Learning Networks. 15 (1),45-57.

[12] Malaya, B. (2020). Modular Distance Learning: Here's what you need to know. Retrieved from https://www.whatalife.ph/modulardistance-learning-heres-what-you-need-to-know/ on March 02, 2021.

[13] Nguyen, T. (2017). Undergraduate Students' Use of Facebook. Master's thesis in Media Education. 1-66pp.

[14] Oducado, R. M. F., et al. (2019). Belitung Nursing Journal. 5(3):116-122 Retrieved from:https://belitungraya.org/BRP/index.php/bnj/index on March 02, 2021.

[15] Sakketa, T. G., \&Khoeber, L. (2020). The COVID-19 Pandemic Crises and Poor People's Struggle for Survival: How Should Governments in Low-Income Countries Respond and What Resources Are Needed?'.Zentrum fur Entwick lungs for schung $(Z E F)$, Policy Brief 33, 1-3.

[16] Sumner et. al. (2020). Estimates of the impact of COVID-19 on global poverty. WIDER Working Paper.doi: 10.37188/UNUWIDER/2020/800-9.

[17] Tankovska, H. (2021, FEBRUARY 9). Facebook access penetration 2021, by device. Retrieved from https://www.statista.com/statistics/377808/distribution-offacebook-users-by-device/ on March 02, 2021 